\title{
11. MIOCENE OXYGEN AND CARBON ISOTOPE STRATIGRAPHY OF PLANKTONIC FORAMINIFERS AT SITES 709 AND 758, TROPICAL INDIAN OCEAN ${ }^{1}$
}

\author{
E. Vincent, ${ }^{2}$ N. J. Shackleton, ${ }^{3}$ and M. A. Hall ${ }^{3}$
}

\begin{abstract}
Oxygen and carbon isotope records are presented for the planktonic foraminifers Dentoglobigerina altispira and Globigerinoides sacculifer (shallow-dwelling species) and Globoquadrina venezuelana (deep-dwelling species) from Miocene sediments at two Ocean Drilling Program sites, located at depths of near $3000 \mathrm{~m}$, in the western (Site 709) and eastern (Site 758) tropical Indian Ocean. The planktonic isotope record at Site 709 is compared with the benthic isotope record obtained at this site by Woodruff et al. (1990).

The isotope stratigraphy is related to the biostratigraphy and the available magnetostratigraphy at the sites. Despite varying sampling density, incompleteness of isotopic records, and the condensed (or even disturbed) nature of parts of the sequences, a number of chronostratigraphic isotopic signals previously recognized in the equatorial Pacific and at other tropical Indian Ocean sites are identified.
\end{abstract}

\section{INTRODUCTION}

Stable isotope records of carbonate pelagic sections have become a standard means of evaluating Cenozoic oceanographic changes (e.g., Savin et al., 1975; Shackleton and Kennett, 1975; Savin and Douglas, 1985; Miller et al., 1987, among many others). In addition they provide very useful correlatable time markers because isotopic changes can be matched on both local and global scales.

This potential has been realized for some time for the Pleistocene, yielding a time-resolution as fine as $5000 \mathrm{yr}$ (e.g., Imbrie et al., 1984). It is now rapidly becoming appreciated for the Pliocene with an increasing number of high-resolution studies in recent years (e.g., Shackleton and Hall, 1984, 1990; Ruddiman et al., 1986; Raymo et al., 1989; Farrell and Janecek, this volume). Miocene stratigraphy, however, is still at a disadvantage with respect to Pliocene-Pleistocene stratigraphy in that time control remains unsatisfactory. A few high-resolution isotopic studies in Miocene sediments show promise (e.g., Woodruff et al., 1981; Shackleton, 1982; Pisias et al., 1985; Keigwin, 1987) but much progress is required for firmer chronostratigraphic control to open the avenue for extensive high-resolution studies throughout the Miocene.

Miocene biochronologic models constructed by Berggren et al. (1985) and Barron et al. (1985), using the geomagnetic polarity time scale (GPTS) of Berggren et al. (1985), are now widely applied. Today, however, discrepancies are still common in the sequencing of biostratigraphic events involving various fossil groups and between various sites.

In addition to magnetostratigraphy, other independent means for calibration of biostratigraphic events on a global scale are provided by oxygen and carbon isotope stratigraphy. Once an isotopic signal is shown to be global it can be used for testing the synchroneity of paleontological datums in various regions.

\footnotetext{
${ }^{1}$ Weissel, J., Peirce, J., Taylor, E., Alt, J., et al., 1991. Proc. ODP, Sci. Results, 121: College Station, TX (Ocean Drilling Program).

${ }^{2}$ Laboratoire de Géologie Océanique, Université Pierre et Marie Curie, 4 Place Jussieu, 75252 Paris Cedex 05, France.

${ }^{3}$ University of Cambridge, Subdepartment of Quaternary Research, Godwin Laboratory, Free School Lane, Cambridge CB2 3RS, United Kingdom.
}

Very few multiple isotope stratigraphies for both planktonic and benthic records are available for the entire Miocene, although such records are necessary to glean information on oceanic conditions simultaneously at the water surface and at the seafloor. Multispecies isotope stratigraphies obtained from shallowdwelling planktonic, deep-dwelling planktonic, and benthic foraminifers at four Deep Sea Drilling Project (DSDP) sites in the tropical Indian Ocean (see Fig. 1) for the entire Miocene were presented by Vincent et al. (1985). Their study, however, was hampered by disturbance in these sedimentary sequences, which was partly due to rotary coring.

We present here Miocene planktonic isotopic records at Ocean Drilling Program (ODP) Sites 709 and 758 in the tropical Indian Ocean (Fig. 1) using the same shallow-dwelling and deepdwelling species analyzed by Vincent et al. (1985). The benthic isotope record obtained by Woodruff et al. (1990) at Site 709, from samples different than those used in the present study, is compared to our planktonic record at this site. The Miocene sequences analyzed in the present study were recovered by hydraulic piston coring and extended core barrel techniques and thus have an advantage with respect to the records previously analyzed by Vincent et al. (1985) in that they are free of disturbance resulting from rotary drilling. They also enlarge the geographic area covered by these four sites, which will allow more detailed paleoceanographic reconstruction of the Miocene tropical Indian Ocean.

\section{DESCRIPTION OF SITES}

The two ODP sites analyzed in this study, as well as the four DSDP sites previously studied by Vincent et al. (1985), lie today under equatorial water masses (Fig. 1).

Site 709, cored during Leg 115 , is located at $3049 \mathrm{~m}$ water depth, in a small basin perched near the summit of the Madingley Rise, which is a topographic high between the Carlsberg Ridge and the northern Mascarene Plateau (Fig. 1; Table 1; Backman, Duncan, et al., 1988). Site 758, cored during Leg 121 , is located at $2935 \mathrm{~m}$ water depth on the northern end of the Ninetyeast Ridge (Fig. 1; Table 1; Peirce, Weissel, et al., 1989). At both sites multiple advanced hydraulic piston coring (APC) was completed down to depths of approximately 190 meters below seafloor (mbsf) at Site 709 and $100 \mathrm{mbsf}$ at Site 758. Below these depths, the lower Neogene was retrieved by using extended core barrel 


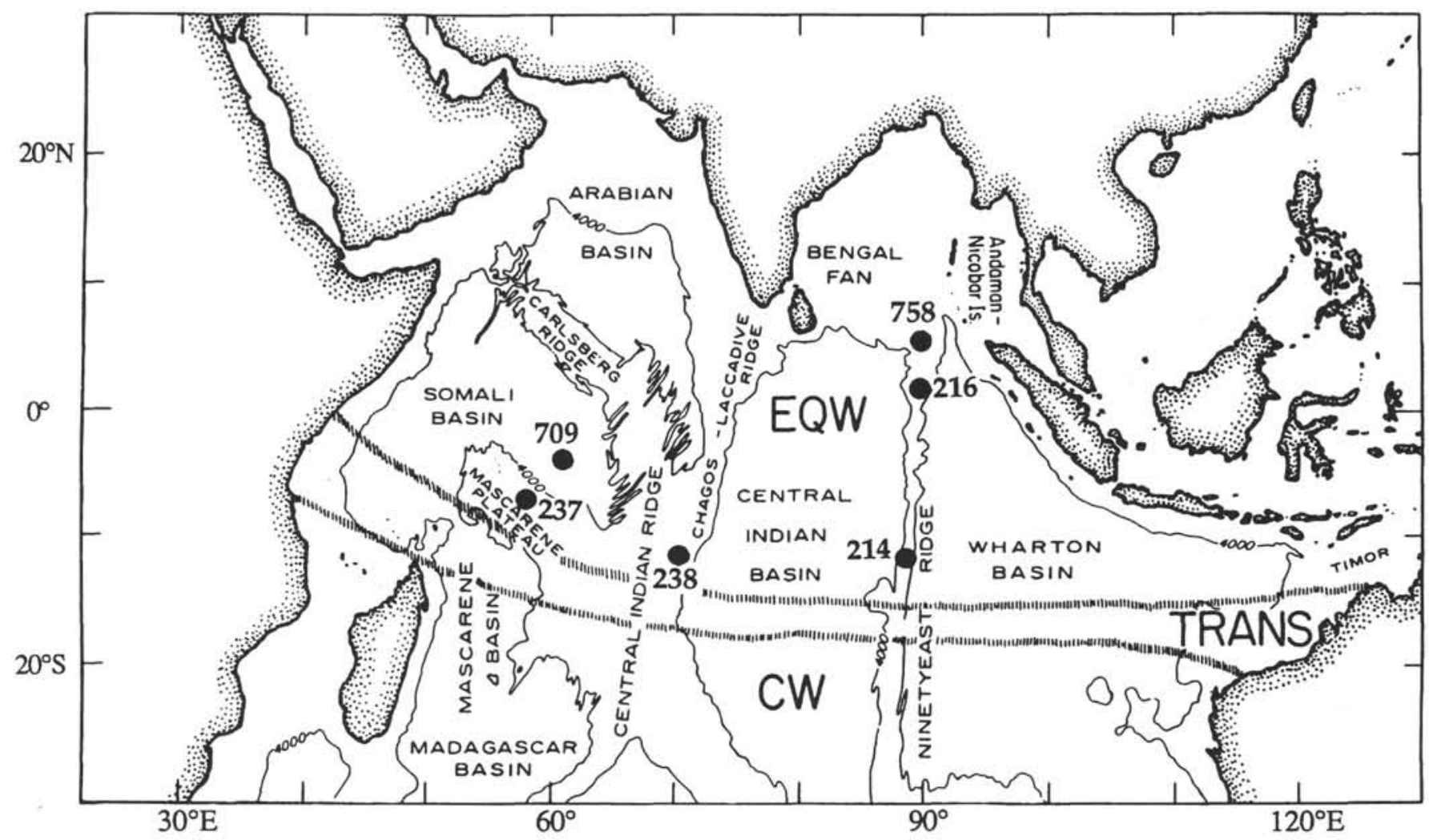

Figure 1. Location map of DSDP/ODP sites in the tropical Indian Ocean. EQW = equatorial water, $\mathrm{CW}=$ central water; TRANS = tropical-subtropical transition zone. Modified from Vincent et al. (1985).

Table 1. Location and water depth of holes analyzed in this study.

\begin{tabular}{cclccc}
\hline Leg & Hole & \multicolumn{1}{c}{ Geographical area } & Latitude & Longitude & $\begin{array}{c}\text { Water depth } \\
(\mathrm{m})\end{array}$ \\
\hline 115 & $709 \mathrm{C}$ & Madlingley Rise & $03^{\circ} 54.90^{\prime} \mathrm{S}$ & $60^{\circ} 33.10^{\prime} \mathrm{E}$ & 3049 \\
121 & $758 \mathrm{~A}$ & Northern Ninetyeast Ridge & $05^{\circ} 23.05^{\prime} \mathrm{N}$ & $90^{\circ} 21.67^{\prime} \mathrm{E}$ & 2935 \\
\hline
\end{tabular}

techniques (see Figs. 2 to 4 ). Good recovery was obtained at both sites yielding apparently continuous Miocene records.

The Miocene sequences are about $140 \mathrm{~m}$ and $125 \mathrm{~m}$ thick at Sites 709 and 758 , respectively, with a condensed middle Miocene section at both sites. Sedimentation rates are similar at both sites. Average values for both entire lower Miocene intervals are approximately $8 \mathrm{~m} / \mathrm{m}$.y., decreasing to 5 and $3 \mathrm{~m} / \mathrm{m}$.y. for the middle Miocene at Sites 709 and 758, respectively, and increasing to $10 \mathrm{~m} / \mathrm{m}$.y. for the upper Miocene. In sections for which we obtained continuous isotopic records, our sampling interval, which is typically $1.5 \mathrm{~m}$, corresponds thus to a time interval of roughly 200,000 yr for the lower Miocene, 320,000 and 500,000 $\mathrm{yr}$ for the middle Miocene, and 150,000 $\mathrm{yr}$ for the upper Miocene.

The sediments consist of calcareous ooze with a calcium carbonate content typically greater than $85 \%$. Calcareous plankton is abundant throughout the sequences. Foraminiferal faunas are generally moderately well preserved with varying preservational states downcore.

Three holes were cored at Site 709. Calcareous nannofossil analyses of the three holes (Backman, Duncan, et al., 1988; Rio et al., 1990) have shown that the three Miocene stratigraphic sequences retrieved were nearly identical. Shore-based studies for calcareous nannofossils (Rio et al., 1990) and planktonic foraminifers (Vincent and Toumarkine, 1990) were concentrated on Hole $709 \mathrm{C}$, which is therefore used here for planktonic isotope stratigraphy. Woodruff et al. (1990), however, used samples from Hole $709 \mathrm{~B}$ for benthic isotope stratigraphy. Both benthic and planktonic isotopic records are combined in Figures 2 and 3. Selected calcareous nannofossil events in both Holes 709B and 709C are presented in Figure 2, illustrating the good biostratigraphic correlations between the two holes. Biostratigraphic disturbance at Site 709 , however, is not uncommon, and is evidenced by reworking in microfossil assemblages in parts of the sequences. Biostratigraphic disorder is particularly marked in the lower and middle Miocene by anomalous stratigraphic inversions, which may easily escape observations depending on the stratigraphic location of samples examined. Rio et al. (1990), who conducted detailed quantitative studies of calcareous nannofossil assemblages, observed within the interval 170-135 mbsf (see Fig. 3) an alternation of sediments indicative of Zone CN2 (containing Sphenolithus belemnos and Triquetrorhabdulus carinatus) and sediments belonging to Zones CN3 or CN4 (containing Sphenolithus heteromorphus) with little or no detectable mixing in the assemblages. These stratigraphic inversions, which are not asso- 


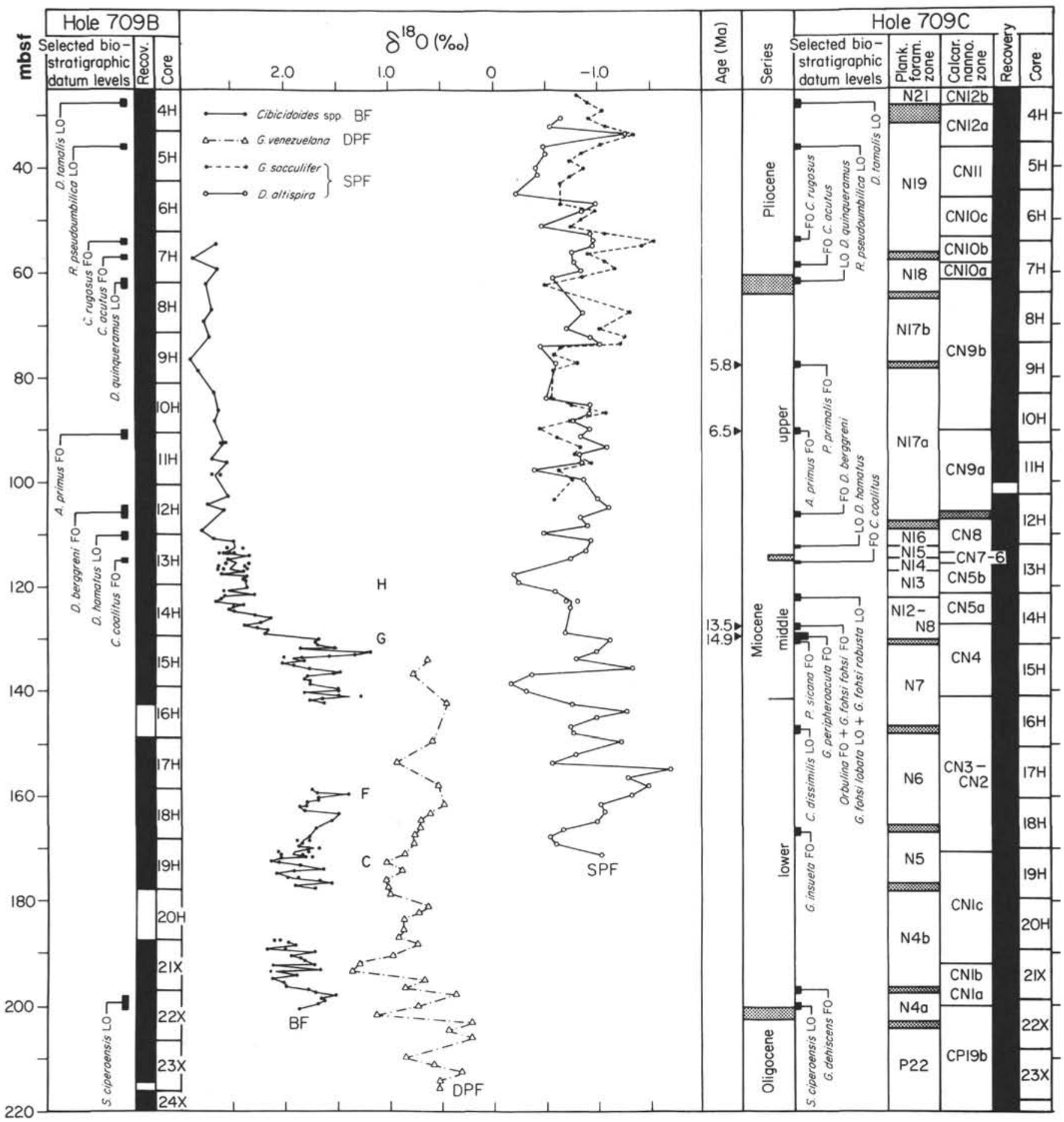

Figure 2. Oxygen isotope stratigraphy at Site 709. Planktonic oxygen isotope compositions for the shallow-dwelling species (SPF, Dentoglobigerina altispira and Globigerinoides sacculifer) and the deep-dwelling species (DPF, Globoquadrina venezuelana) are from Hole 709C (data in Table 2). Benthic oxygen isotope compositions for Cibicidoides spp. (BF) are from Hole 709B (from Woodruff et al., 1990). Duplicate isotope analyses are plotted and a line is drawn through the mean values of the duplicates. Biostratigraphic zonations and biostratigraphic datums for Hole 709C, at right, are from Rio et al. (1990) for calcareous nannofossils and Vincent and Toumarkine (1990) for planktonic foraminifers. Biostratigraphic datums in Hole 709B, at left, are from Rio et al. (1990). FO = first occurrence; LO = last occurrence. Ages are those of selected biostratigraphic datums from Berggren et al. (1985). The letters C, F, G, and H next to the isotopic curves correspond to the stratigraphic levels defined by Vincent and Killingley (1985). 


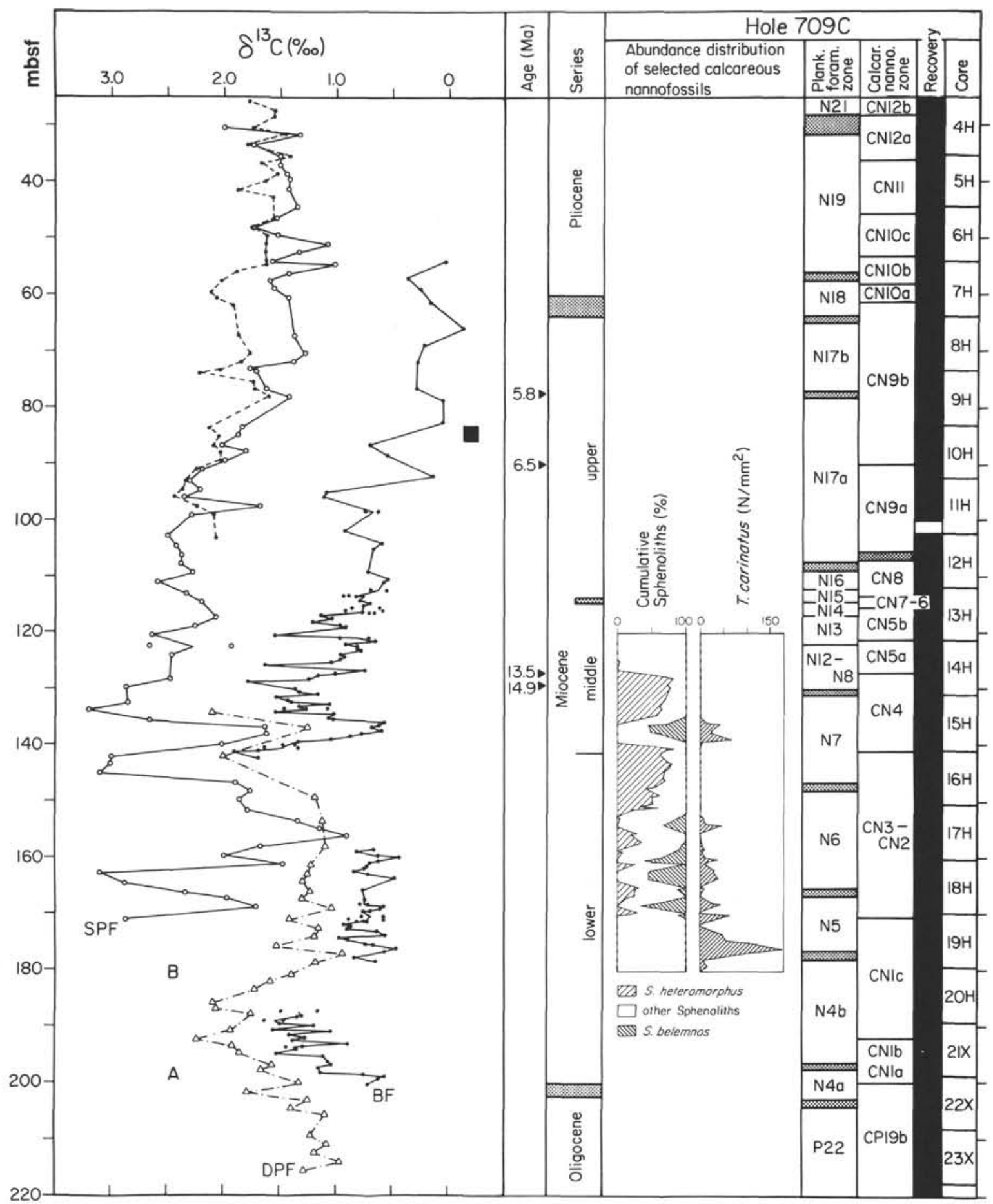

Figure 3. Carbon isotope stratigraphy at Site 709. Planktonic carbon isotope compositions for the shallow-dwelling species (SPF, Dentoglobigerina altispira and Globigerinoides sacculifer) and the deep-dwelling species (DPF, Globoquadrina venezuelana) are from Hole 709C (data in Table 2). Benthic carbon isotope compositions for Cibicidoides spp. (BF) are from Hole 709B (from Woodruff et al., 1990). Duplicate isotope analyses are plotted and a line is drawn through the mean values of the duplicates. Biostratigraphic zonations in Hole 709C are from Rio et al. (1990) and Vincent and Toumarkine (1990). Plots of abundance distribution of selected calcareous nannofossils are from Rio et al. (1990). Sphenolithid cumulative percentages are based on a count of 100 specimens. The abundance of Triquetrorhabdulus carinatus is expressed in the number of specimens found per unit area in the slide. The letters A and B next to the isotopic curves correspond to the stratigraphic levels defined by Vincent and Killingley (1985). The vertical black bar at right of the isotopic curve corresponds to the "Chron 6 carbon shift." 


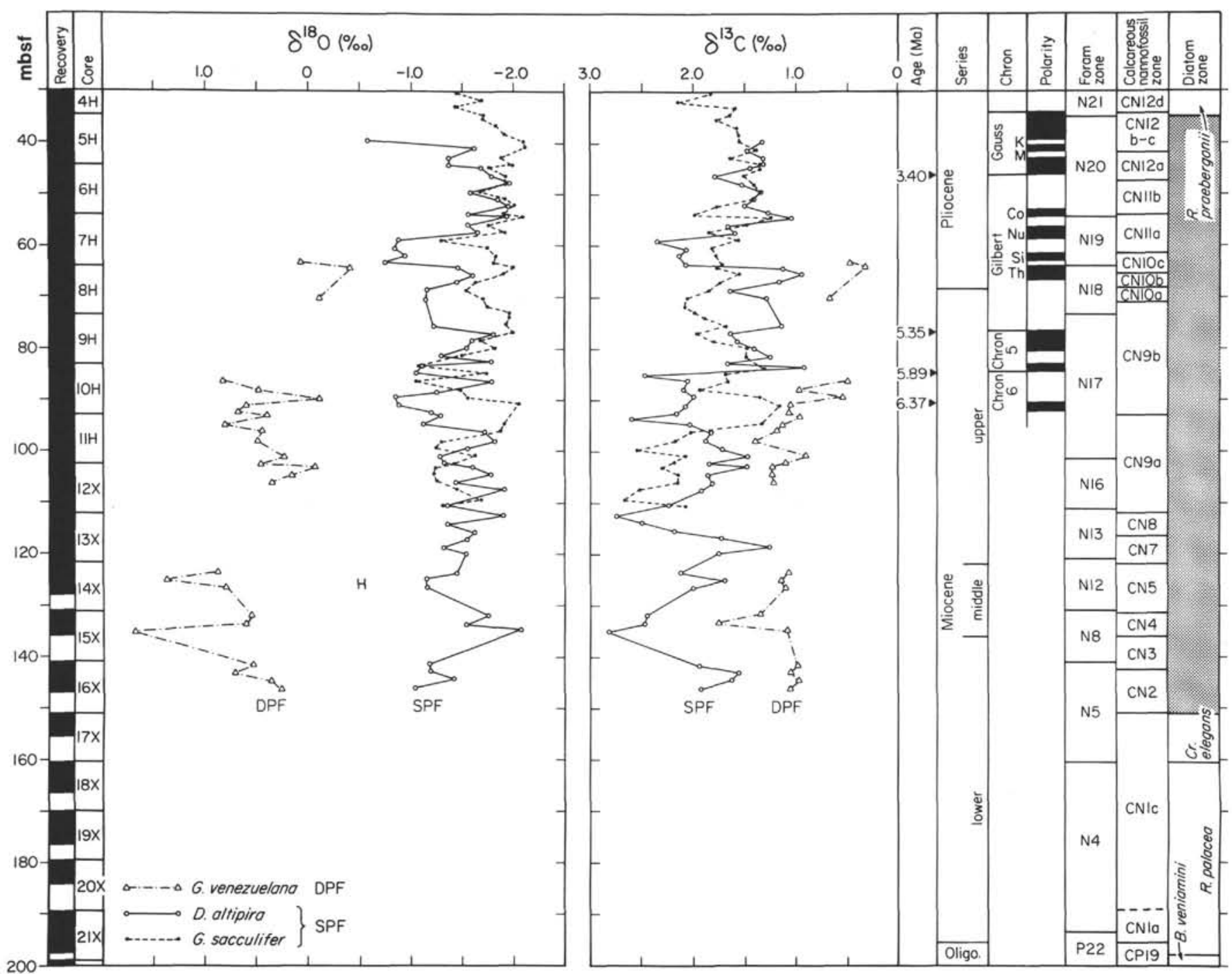

Figure 4. Planktonic oxygen and carbon isotope stratigraphy in the Miocene of Hole 758A from the shallow-dwelling species (SPF) Dentoglobigerina altispira and Globigerinoides sacculifer and the deep-dwelling species (DPF) Globoquadrina venezuelana (data in Table 3). Biostratigraphic zonations are from Fourtanier (this volume) for diatoms, Resiwati (this volume) for calcareous nannofossils, and Peirce, Weissel, et al. (1989) for planktonic foraminifers. Magnetostratigraphy according to Peirce, Weissel, et al. (1989). Ages are those of selected paleomagnetic reversals from Berggren et al. (1985).

ciated with sedimentologic evidence of turbidites or slumping, represent cryptoturbidites. The $\mathrm{CN} 2 / \mathrm{CN} 3$ nannofossil zonal boundary is not identified in Figures 2 and 3, whereas the N6/N7 foraminifer zonal boundary is placed in Core $115-709 \mathrm{C}-16 \mathrm{H}$. These two zonal boundaries usually approximate each other in undisturbed sedimentary sequences.

Site 709 lacks magnetostratigraphy but a largely continuous magnetostratigraphic sequence was obtained at nearby Site 710 (Schneider and Kent, 1990). Site 710 lies in $3824 \mathrm{~m}$ water depth and is largely affected by carbonate dissolution. Calcareous nannofossils, however, are preserved and their biostratigraphic sequence at this site can be compared to that at Site 709 , providing a link for correlation of the isotopic record at Site 709 to the GPTS. In their interpretation of the biostratigraphic and magnetostratigraphic sequences recovered at Site 710, Backman et al. (1990) proposed substantial revision of the currently accepted Miocene nannofossil chronology as given by Berggren et al. (1985). Additional low-latitude magnetostratigraphic sequences are needed to support the several amendments proposed by Backman et al. The time scale of Berggren et al. (1985) is, therefore, used in this study. An excellent geomagnetic-reversal record, from the Brunhes Chron down to Chron 6, was obtained in two holes at Site 758 (Peirce, Weissel, et al., 1989). From detailed high-resolution studies of various records of the last $7 \mathrm{Ma}$ at this site, Farrell and Janecek (this volume) constructed a composite depth section from Holes 758A and 758B that splices across recovery gaps at core breaks. These authors report that despite excellent core recovery (100\% to $105 \%)$, sediment is missing between each successive APC cores, suggesting that $10 \%$ of the APC-cored sequence was not recovered in each hole. These findings bear considerable implications for high-resolution studies. The depths of the magnetic-reversal boundaries obtained by Farrell and Janecek (this volume) from their composite depth section are generally $10 \mathrm{~m}$ greater in the upper Miocene section than those given by Peirce, Weissel, et al. (1989). Because a high-resolution study was not intended in this paper (which is limited to Hole $758 \mathrm{~A}$ ), the composite depths given by Farrell and Janecek (this volume) were not used here. The depths of chron and subchron boundaries shown in Figure 4 are taken from Peirce, Weissel, et al. (1989). 


\section{SPECIES ANALYZED}

We chose Globigerinoides sacculifer, an extant species known to inhabit the ocean surface or mixed layer. Its ${ }^{18} \mathrm{O} /{ }^{16} \mathrm{O}$ ratio is among the lowest of modern planktonic foraminifers and it has been used extensively as a tool for sea-surface temperature reconstruction in the Pleistocene and the Pliocene. High-resolution isotopic records of $G$. sacculifer have been established for the Pliocene-Pleistocene sequences at Site 709 (Shackleton and Hall, 1990) and Site 758 (Farrell and Janecek, this volume).

G. sacculifer records the lowest $\delta^{18} \mathrm{O}$ planktonic foraminiferal values back into the Miocene (Vincent et al., 1980, 1985; Savin et al., 1985). This species is not sufficiently abundant in all upper Miocene samples for analysis and is virtually absent in the lower and middle Miocene sequences. We therefore chose Dentoglobigerina altispira to represent the surface-water environment throughout the Miocene. This species became extinct at the end of the Pliocene and has no modern representative. D. altispira s.s. evolved in the early Miocene, within Zone N4b. The species remains rare, however, throughout the lower part of its stratigraphic range in the Indian Ocean sequences, becoming common only within mid-Zone N5. Furthermore, the morphotypes found below this level deviate from the typical high-spired $D$. altispira s.s. commonly found above, throughout the remainder of the Miocene and lower Pliocene, which were analyzed here and at other Indian Ocean sites (Vincent et al., 1985). We have therefore excluded $D$. altispira s.l. in the lower lower Miocene sequences from our analyses because records of mixed species, of course, can show spurious variations owing to changes in the mixture rather than in isotopic composition of components. Further taxonomic and isotopic studies are needed on this group.

In sections for which isotopic data were obtained for both $G$. sacculifer and D. altispira (see Figs. 2 to 4 ), both oxygen and carbon isotopic signatures are quite similar for the two species in some intervals, whereas in others there is a distinct separation between the signals of the two species (as much as $0.8 \%$ apart). Overall, D. altispira is enriched in oxygen and depleted in carbon, although in a few intervals the reverse situation was seen. These observations, which were also made by Vincent et al. $(1980,1985)$ for other Indian Ocean records, remain to be interpreted.

We chose Globoquadrina venezuelana as a deep-dwelling planktonic foraminifer. This is also an extinct species. Its direct descendant, $G$. conglomerata, has adult populations living predominantly in deep waters (deeper than $100 \mathrm{~m}$ : Bé, 1977) and ${ }^{18} \mathrm{O} /{ }^{16} \mathrm{O}$ ratios that are among the highest of Holocene planktonic foraminifers (Berger et al., 1978). G. venezuelana retains the highest ${ }^{18} \mathrm{O}$ values of planktonic foraminifers throughout the Miocene, suggesting it is a reliable record of the deep surface water (Vincent et al., 1980, 1985; Vincent and Killingley, 1985; Savin et al., 1985).

Taxonomic ambiguities of $G$. venezuelana in a number of intervals at Sites 709 and 758 remain to be resolved. Therefore, due to the time constraints for the publication of this paper, the isotopic record for $G$. venezuelana presented here is somewhat discontinuous. Only typical morphotypes (similar to those illustrated by Parker, 1967; Kennett and Srinivasan, 1983), from samples where the species is common, have been analyzed so far.

The benthic foraminifers chosen by Woodruff et al. (1990) to establish the deep-water isotopic record from Hole 709B are species of Cibicidoides (primarily C. wuellerstorfi and C. kullenbergi). Species of Cibicidoides are commonly used in isotopic oceanographic reconstructions because their carbon isotopic composition appears to reflect the $\delta^{13} \mathrm{C}$ values of dissolved $\mathrm{HCO}_{3}$ in seawater at the sediment/water interface most closely (Duplessy et al., 1984; Shackleton et al., 1984, among others).

\section{METHODS}

All samples $\left(10 \mathrm{~cm}^{3}\right)$ were disaggregated by soaking overnight in buffered Calgon solution at room temperature, washed over a $63-\mu \mathrm{m}$ sieve, and dried at less than $60^{\circ} \mathrm{C}$. About 30 specimens of each planktonic foraminiferal species were picked from the fraction greater than $250 \mu \mathrm{m}$. In order to minimize noise arising from isotopic change during ontogeny (Berger et al., 1978), foraminifers were selected in distinct size ranges, usually 300 to $350 \mu \mathrm{m}$ for D. altispira and $G$. sacculifer, and 350 to $450 \mu \mathrm{m}$ for $G$. venezuelana. The size fractions, however, were not as narrowly selected as in previous studies conducted by Vincent and Killingley (1985) and Vincent et al. (1985), who separated the various size fractions by sieving before picking. In this study, test sizes were visually estimated under the microscope. In some cases when selected species were rare, smaller or larger specimens were included.

Isotopic analyses were performed with a VG Isogas SIRA triple collector mass spectrometer using a common $\mathrm{H}_{3} \mathrm{PO}_{4}$ acid reservoir. Four analyses of a standard carbonate preceded, and another few followed, each set of 30 foraminiferal analyses. Results are given to the PDB standard.

\section{RESULTS}

Results of isotopic analyses of planktonic foraminifers are given in Tables 2 and 3 and are plotted vs. depth below seafloor and biostratigraphic zonation in Figures 2 through 4. Approximately 240 foraminiferal analyses were performed to determine both ${ }^{18} \mathrm{O} /{ }^{16} \mathrm{O}$ and ${ }^{13} \mathrm{C} /{ }^{12} \mathrm{C}$ ratios.

For practicality, in the following discussion we shall refer to shallow-dwelling planktonic foraminifers as SPF, to deepdwelling ones as DPF, and to benthic species as BF.

A number of features of stratigraphic value in the isotopic and calcium carbonate records of the continuous expanded lower and middle Miocene sequences in the central equatorial Pacific at DSDP Sites 574 and 575 were identified by Vincent and Killingley (1985). These expanded sequences, recovered with minimum disturbance (hydraulic piston coring was performed at Site 575), yielded excellent siliceous biostratigraphic control and some paleomagnetic data. Vincent and Killingley estimated ages for the chemostratigraphic markers, which they labeled in stratigraphic order from A to $\mathrm{H}$. These authors correlated these isotopic markers with those identified at DSDP Site 289 on the Ontong-Java Plateau in the western equatorial Pacific by Woodruff et al. (1981) (see isotopic records at Sites 574,575 , and 289 as reproduced by Theyer et al., 1989, in their figs. 10 and 11). Using biostratigraphic correlations, Vincent et al. (1985) were able to recognize a number of these synchronous Pacific signals in the Miocene records of Indian Ocean Sites 214, 216, 237, and 238 (Fig. 1).

In the present study, despite varying sampling density, incompleteness of isotopic records, and the condensed (or even disturbed) nature of parts of the sequences, a number of these isotopic signals are recognizable at Sites 709 and 758. These are shown in Figures 2 to 4 (levels $\mathrm{A}$ to $\mathrm{H}$ ). Their depths below seafloor plotted against time fall approximately on the smoothed sedimentation-rate curves constructed at both sites from biostratigraphic and paleomagnetic data.

At this juncture no attempt is made to construct plots of isotopic curves against age because of (1) the incompleteness of the isotopic records presented here and (2) because the biostratigraphic records from the two sites are not yet well integrated with each other, nor are they integrated with records from the four other Indian Ocean sites studied previously or those from other ocean basins. 
In the following we use "warming" and "cooling" without specifically identifying for each event whether local temperature or distant ice volume change is the actual origin of the isotopic change.

\section{Oxygen Isotope Stratigraphy}

The DPF isotopic record in Hole 709C shows an overall trend of increasing $\delta^{18} \mathrm{O}$ values spanning the Oligocene/Miocene boundary with values near $0.5 \%$ in the uppermost Oligocene reaching a maximum of about $1.3 \%$ at $194 \mathrm{mbsf}$ in lowermost Zone N4b. In the overlying interval up to approximately 181 mbsf, in uppermost Zone $\mathrm{N} 4$ and mid-Zone $\mathrm{CN} 1 \mathrm{c}, \delta^{18} \mathrm{O}$ values decrease to about $0.6 \%$, then increase again (up to $172.5-175$ mbsf) to reach values of about $1.25 \%$ at stratigraphic level $\mathrm{C}$ in lowermost Zone N5 and upper Zone CN1c.

Level C was defined by Vincent and Killingley (1985) in DPF oxygen isotope records at equatorial Pacific DSDP Sites 575 and 574 as marking the beginning of a regular decrease in $\delta^{18} \mathrm{O}$ values throughout the upper half of the lower Miocene. At these two sites level C in Zones CN1c and N5 was assigned an approximate age of $19.5 \mathrm{Ma}$, whereas level $\mathrm{F}$, marking the termination of the decreasing trend in $\delta^{18} \mathrm{O}$ in the uppermost lower Miocene, within Zone $\mathrm{CN} 3$ and undifferentiated Zones N7-N8, was paleomagnetically dated within magnetic anomaly $5 \mathrm{C}$ to an approximate age of 16.5 Ma. A similar decreasing $\delta^{18} \mathrm{O}$ trend from levels $\mathrm{C}$ to $\mathrm{F}$ was also recognized in the same biostratigraphic position in DPF records at Indian Ocean Sites 216, 237, and 238, where it is also paralleled by a decreasing trend in SPF records and a less pronounced one in BF records (Vincent et al., 1985),

At Site 709 a decreasing DPF $\delta^{18} \mathrm{O}$ trend is well marked from $173 \mathrm{mbsf}$ (level C) to about $160 \mathrm{mbsf}$ and is also paralleled by a decreasing $\delta^{18} \mathrm{O}$ trend in SPF and BF. Level F is tentatively placed at $160 \mathrm{mbsf}$.

In the equatorial Pacific and at previously studied tropical Indian Ocean sites, Vincent and Killingley (1985) and Vincent et al. (1985) noted above level $F$ an increase of $\delta^{18} \mathrm{O}$ values in all three BF, DPF, and SPF records. It is followed in the three records by one or two excursions toward lower $\delta^{18} \mathrm{O}$ values, which again reach minima close to those of level $\mathrm{F}$, throughout an interval spanning the lower/middle Miocene boundary and terminating in Zone CN4. It is in this interval (located in Zones CN3-CN4) that the lightest $\delta^{18} \mathrm{O}$ values of $\mathrm{BF}$ in the entire Neogene occur, just preceding the onset of the major mid-Miocene deep-water cooling. This is seen in records of various areas of the world ocean.

At Site 709 the interval of $\delta^{18} \mathrm{O}$ minima spanning the lower/middle Miocene boundary occurs between 160 and 132 mbsf. In this interval the BF record is discontinuous. A minimum of $1.35 \%$ occurs at $160 \mathrm{mbsf}$, and a minimum of $1.1 \%$ at 132 mbsf. Two minima of $0.5 \%$ occur in the DPF record at about 160 and $141 \mathrm{mbsf}$, and two minima of about $-1.5 \%$ in the SPF record are at 155 and 135 mbsf. Interpretation of isotopic data in this entire interval at Site 709 should be done with great caution due to the stratigraphic disturbance evidenced by detailed quantitative studies of calcareous nannofossil assemblages (Rio et al., 1990) previously mentioned.

The significant middle Miocene enrichment in deep-water ${ }^{18} \mathrm{O}$, recorded throughout the world ocean by an increase of about $1 \%$ in benthic $\delta^{18} \mathrm{O}$ values, is generally interpreted as the combined effects of cooling deep waters and growth of the Antarctic Ice Sheet. High-resolution studies of this interval at equatorial Pacific Site 574 (Pisias et al., 1985) and Site 289 (Woodruff et al., 1981) reveal a step-like, rapid change (an increase of approximately $0.5 \%$ ), possibly taking as little as $30,000 \mathrm{yr}$. This abrupt step in the benthic oxygen isotope record corresponds to level G of Vincent and Killingley (1985) at about 14.6 Ma, within Zone CN4 and approximating the Zone N9/N10 boundary. This step is well marked in the high-resolution BF record of Hole 709B between 128 and 130 mbsf. Sediments at these depths in Hole $709 \mathrm{C}$ belongs to upper Zone CN4, within undifferentiated Zones N8-N12. Foraminiferal zones were not differentiated in this interval because of (1) the rarity of diagnostic taxa and (2) the very condensed nature of the stratigraphic interval. The latter is evidenced by the first occurrences (FO) of Globorotalia peripheroacuta and $G$. fohsi fohsi, dated at 14.9 and $13.5 \mathrm{Ma}$, respectively, only $3 \mathrm{~m}$ apart (see Fig. 2 ). The $G$. peripheroacuta FO (which marks the N9/N10 boundary) in Hole $709 \mathrm{C}$ is coincidental with level $\mathrm{G}$ in Hole 709B.

The isotopic step $\mathrm{G}$ appears to be an excellent chronostratigraphic marker and discrepancies in its biostratigraphic position relative to the foraminiferal zonation at different sites were discussed by Vincent and Killingley (1985). They appear to result from differing biostratigraphic interpretations of foraminiferal data by various workers.

Following the abrupt step of ${ }^{18} \mathrm{O}$ enrichment, the $\delta^{18} \mathrm{O}$ values of BF continue to increase steadily upward to a level at the equatorial Pacific Sites 289 and 575 that approximates the Zone $\mathrm{N} 12 / \mathrm{N} 13$ and $\mathrm{CN} 5 \mathrm{a} / \mathrm{CN} 5 \mathrm{~b}$ boundaries (level $\mathrm{H}$ at about $12.5 \mathrm{Ma}$ ). The same increase is observed at Site 709 in the BF record, in which, above the abrupt step at $130 \mathrm{mbsf}, \delta^{18} \mathrm{O}$ values continue to increase to values of about $2.5 \%$ up to $123 \mathrm{mbsf}$, near the Zone $\mathrm{N} 12 / \mathrm{N} 13$ and $\mathrm{CN} 5 \mathrm{a} / \mathrm{CN} 5 \mathrm{~b}$ boundaries. Above this level the $\delta^{18} \mathrm{O}$ values of BF remain high throughout the remainder of the Neogene.

Above the interval of minimum $\delta^{18} \mathrm{O}$ values in the lowermost middle Miocene, the DPF and SPF records of previously studied tropical Indian Ocean sites show an enrichment in ${ }^{18} \mathrm{O}$ synchronous with that of the BF record. The $\delta^{18} \mathrm{O}$ records of SPF and DPF, however, do not show the mid-Miocene cooling as clearly as $\mathrm{BF}$. At level $\mathrm{H}$, whereas $\delta^{18} \mathrm{O}$ values of $\mathrm{BF}$ remain high, there is a distinct inflection point in the DPF and SPF $\delta^{18} \mathrm{O}$ curves toward decreasing values, which reflects warming in surface and subsurface waters.

If ice buildup caused the mid-Miocene $\delta^{18} \mathrm{O}$ increase, it must have been at least partially compensated for by warming of tropical surface waters. In the absence of such compensation, Vincent et al. (1985) argued that no more than about one-third of the change can be assigned to an ice effect. The ice effect, of course, changes the average composition of the entire water column and must affect BF, DPF, and SPF in the same manner.

At Site 709, after the middle Miocene cooling in both deep and surface water recorded between 135 and 118-120 mbsf (by a total $\delta^{18} \mathrm{O}$ increase of about $1.25 \%$ in BF and about $1 \%$ in SPF), warming of surface water is evidenced by decreasing $\delta^{18} \mathrm{O}$ values of SPF above level H. Similar changes are observed in the SPF record at Site 758 in the same biostratigraphic position. The latter shows an increase in $\delta^{18} \mathrm{O}$ values (about $0.8 \%$ ) between 135 and 125 mbsf followed by a decrease above 125 mbsf (which corresponds to level $\mathrm{H}$ ). At both sites the DPF record is too discontinuous to be interpreted.

Stratigraphic level $\mathrm{H}$ marks the upward-increasing separation of the benthic and planktonic $\delta^{18} \mathrm{O}$ records. At Sites 214,216 , and 238 the upward-decreasing trend in $\delta^{18} \mathrm{O}$ values of SPF and DPF above level $\mathrm{H}$ is distinct up into the upper Miocene despite large amplitude variations. Its termination, however, is not always clearly identified and may vary from site to site in Zones CN8 and $\mathrm{N} 16$ or near the Zone CN8/CN9 and N16/N17 boundaries. From then on, through the remainder of the upper Miocene, large amplitude fluctuations occur with no clear trend. Similar variations are shown by the $\delta^{18} \mathrm{O}$ values of SPF at both Sites 709 and 758 where the record of $D$. altispira appears to terminate a decreasing trend near $108 \mathrm{~m}$ at Site 758 (in Zones CN8 and N16) and near $105 \mathrm{~m}$ at Site 709 (at the Zone CN8/CN9 boundary and 
Table 2. Oxygen and carbon isotope composition of planktonic foraminifers from Hole $709 \mathrm{C}^{\mathrm{a}}$

\begin{tabular}{|c|c|c|c|c|c|c|c|}
\hline \multirow{2}{*}{$\begin{array}{l}\text { Core, section, } \\
\text { interval }(\mathrm{cm})\end{array}$} & \multirow{2}{*}{$\begin{array}{l}\text { Depth } \\
\text { (mbsf) }\end{array}$} & \multicolumn{2}{|c|}{$\begin{array}{c}\text { Dentoglobigerina } \\
\text { altispira }\end{array}$} & \multicolumn{2}{|c|}{$\begin{array}{c}\text { Globigerinoides } \\
\text { sacculifer }\end{array}$} & \multicolumn{2}{|c|}{$\begin{array}{c}\text { Globoquadrina } \\
\text { venezuelana }\end{array}$} \\
\hline & & $\delta^{18} \mathrm{O}$ & $\overline{\delta^{13} \mathrm{C}}$ & $\delta^{18} \mathrm{O}$ & $\overline{\delta^{13} \mathrm{C}}$ & $\delta^{18} \mathrm{O}$ & $\overline{\delta^{13} \mathrm{C}}$ \\
\hline \multicolumn{8}{|l|}{ 115-709C- } \\
\hline $4 \mathrm{H}-1,60-65$ & 25.70 & & & -0.80 & 1.79 & & \\
\hline $4 \mathrm{H}-2,60-65$ & 27.70 & & & -0.91 & 1.54 & & \\
\hline $4 \mathrm{H}-3,60-65$ & 28.70 & & & -1.14 & 1.56 & & \\
\hline $4 \mathrm{H}-4,60-65$ & 30.20 & -0.64 & 2.00 & -0.92 & 1.73 & & \\
\hline $4 \mathrm{H}-5,60-65$ & 31.70 & -0.54 & 1.32 & -1.07 & 1.44 & & \\
\hline $4 H-6,60-65$ & 33.20 & -1.29 & 1.74 & -1.32 & 1.80 & & \\
\hline $5 \mathrm{H}-1,60-65$ & 35.30 & -0.49 & 1.51 & -1.03 & 1.41 & & \\
\hline $5 \mathrm{H}-2,60-65$ & 36.80 & -0.50 & 1.50 & -0.85 & 1.68 & & \\
\hline $5 \mathrm{H}-3,60-65$ & 38.30 & & & -0.64 & 1.52 & & \\
\hline $5 \mathrm{H}-4,60-65$ & 39.80 & -0.42 & 1.43 & -0.89 & 1.61 & & \\
\hline $5 \mathrm{H}-5,60-65$ & 41.30 & -0.44 & 1.43 & -0.73 & 1.88 & & \\
\hline $5 \mathrm{H}-6,60-65$ & 42.80 & & & -0.65 & 1.59 & & \\
\hline $6 \mathrm{H}-1,60-65$ & 44.90 & -0.22 & 1.34 & & & & \\
\hline $6 \mathrm{H}-2,60-65$ & 46.40 & -0.99 & 1.53 & -0.65 & 1.55 & & \\
\hline $6 \mathrm{H}-3,60-65$ & 47.90 & -0.85 & 1.75 & -0.99 & 1.76 & & \\
\hline $6 \mathrm{H}-4,60-65$ & 49.40 & -0.69 & 1.52 & -0.84 & 1.62 & & \\
\hline $6 \mathrm{H}-5,60-65$ & 50.90 & -0.47 & 1.18 & -0.73 & 1.64 & & \\
\hline $6 \mathrm{H}-6,60-65$ & 52.40 & -0.93 & 1.35 & -1.06 & 1.65 & & \\
\hline $6 \mathrm{H}-7,60-65$ & 53.90 & -0.96 & 1.52 & -1.54 & 1.62 & & \\
\hline $7 \mathrm{H}-1,60-65$ & 54.50 & -0.96 & 1.05 & -1.44 & 1.62 & & \\
\hline $7 \mathrm{H}-2,60-65$ & 56.00 & -0.75 & 1.43 & -0.91 & 1.90 & & \\
\hline $7 \mathrm{H}-3,60-65$ & 57.50 & -0.78 & 1.60 & -1.07 & 2.03 & & \\
\hline $7 \mathrm{H}-4,60-65$ & 59.00 & -0.85 & 1.56 & -1.19 & 2.12 & & \\
\hline $7 \mathrm{H}-5,60-65$ & 60.50 & -0.57 & 1.43 & -0.86 & 2.08 & & \\
\hline $7 \mathrm{H}-6,60-65$ & 62.00 & & & -0.50 & 1.93 & & \\
\hline $8 \mathrm{H}-3,60-65$ & 67.20 & -0.87 & 1.38 & -1.31 & 1.86 & & \\
\hline $8 \mathrm{H}-5,60-65$ & 70.20 & -0.70 & 1.27 & -1.05 & 1.78 & & \\
\hline $8 \mathrm{H}-6,60-65$ & 71.70 & -0.93 & 1.39 & -1.27 & 1.85 & & \\
\hline $8 \mathrm{H}-7,60-65$ & 73.20 & -1.02 & 1.77 & -1.23 & 2.05 & & \\
\hline $9 \mathrm{H}-1,60-62$ & 73.80 & -0.45 & 1.72 & -0.64 & 2.20 & & \\
\hline $9 \mathrm{H}-2,60-62$ & 75.30 & -0.59 & 1.75 & -0.59 & 1.75 & & \\
\hline $9 \mathrm{H}-3,60-62$ & 76.80 & -0.61 & 1.65 & -0.83 & 1.73 & & \\
\hline $9 \mathrm{H}-4,60-62$ & 78.30 & -0.56 & 1.60 & -0.56 & 1.60 & & \\
\hline $10 \mathrm{H}-1,60-62$ & 83.50 & -0.51 & 1.85 & -0.55 & 2.14 & & \\
\hline $10 \mathrm{H}-2,60-62$ & 85.00 & -0.92 & 1.88 & -0.76 & 2.05 & & \\
\hline $10 \mathrm{H}-3,60-62$ & 86.50 & -0.92 & 2.03 & -1.08 & 2.10 & & \\
\hline $10 \mathrm{H}-4,60-62$ & 88.00 & -0.75 & 1.82 & -0.74 & 2.04 & & \\
\hline $10 \mathrm{H}-5,60-62$ & 89.50 & -0.93 & 2.05 & -0.45 & 2.02 & & \\
\hline $10 \mathrm{H}-6,60-62$ & 91.00 & -0.85 & 2.20 & -0.61 & 2.25 & & \\
\hline $11 \mathrm{H}-1,60-62$ & 93.10 & -1.10 & 2.34 & -0.85 & 2.35 & & \\
\hline $11 \mathrm{H}-2,60-62$ & 94.60 & -0.83 & 2.23 & -0.77 & 2.38 & & \\
\hline $11 \mathrm{H}-3,60-62$ & 96.10 & -0.85 & 2.39 & -0.94 & 2.44 & & \\
\hline $11 \mathrm{H}-4,60-62$ & 97.60 & -0.40 & 1.69 & -0.62 & 2.26 & & \\
\hline $11 \mathrm{H}-5,60-62$ & 99.10 & -0.87 & 2.30 & -0.74 & 2.11 & & \\
\hline $12 \mathrm{H}-1,120-125$ & 103.40 & -1.01 & 2.49 & -0.59 & 2.09 & & \\
\hline $12 \mathrm{H}-2,120-125$ & 104.90 & -1.11 & 2.43 & & & & \\
\hline $12 \mathrm{H}-3,120-125$ & 106.40 & -0.82 & 2.39 & & & & \\
\hline $12 \mathrm{H}-4,120-125$ & 107.90 & -0.91 & 2.39 & & & & \\
\hline $12 \mathrm{H}-5,120-125$ & 109.40 & -0.47 & 2.28 & & & & \\
\hline $12 \mathrm{H}-6,120-125$ & 110.90 & -0.95 & 2.60 & & & & \\
\hline $13 \mathrm{H}-1,120-125$ & 113.00 & -0.89 & 2.36 & & & & \\
\hline $13 \mathrm{H}-2,120-125$ & 114.50 & -0.74 & 2.20 & & & & \\
\hline $13 \mathrm{H}-4,120-125$ & 117.50 & -0.19 & 2.08 & & & & \\
\hline $13 \mathrm{H}-5,120-125$ & 119.00 & -1.26 & 2.26 & & & & \\
\hline $13 \mathrm{H}-6,120-125$ & 120.50 & -0.61 & 2.68 & & & & \\
\hline & 122.10 & -0.64 & 3.12 & & & & \\
\hline
\end{tabular}

in lowermost Zone N17). Above these levels, the $\delta^{18} \mathrm{O}$ records of both SPF, D. altispira and $G$. sacculifer, show large amplitude variations through the remainder of the Miocene with no clear trend.

\section{Carbon Isotope Stratigraphy}

At Site 709 there is an increase of $\delta^{13} \mathrm{C}$ values in DPF spanning the Oligocene/Miocene boundary, with values of $1.25 \%$ at 205 $\mathrm{m}$ in the uppermost Oligocene to about $2.25 \%$ at $192 \mathrm{~m}$ (in lower Zone N4b), paralleling the increase in $\delta^{18} \mathrm{O}$. A similar overall trend of ${ }^{13} \mathrm{C}$ enrichment of DPF spanning the Oligocene/Miocene boundary was noted by Vincent and Killingley (1985) at equatorial Pacific Site 574. They labeled a sharp increase within the overall trend as level $\mathrm{A}$ at a level approximating the Zone $\mathrm{CN} 1 \mathrm{a} / \mathrm{CN} 1 \mathrm{~b}$ boundary and in lower Zone N4 with an approximate age of $22.7 \mathrm{Ma}$. This level was also identified by Vincent et al. (1985) in the DPF record of previously studied Indian Ocean sites in which the DPF ${ }^{13} \mathrm{C}$ enrichment is paralleled by an enrichment in $\mathrm{BF}^{13} \mathrm{C}$.

At Site 709 level A is placed at $198 \mathrm{mbsf}$. The BF record does not extend below the Oligocene/Miocene boundary but the $\delta^{13} \mathrm{C}$ values show an increase of near $1 \%$ between 200 and 195 mbsf 
Table 2 (continued).

\begin{tabular}{|c|c|c|c|c|c|c|c|}
\hline \multirow{2}{*}{$\begin{array}{l}\text { Core, section, } \\
\text { interval }(\mathrm{cm})\end{array}$} & \multirow{2}{*}{$\begin{array}{l}\text { Depth } \\
\text { (mbsf) }\end{array}$} & \multicolumn{2}{|c|}{$\begin{array}{c}\text { Dentoglobigerina } \\
\text { altispira }\end{array}$} & \multicolumn{2}{|c|}{$\begin{array}{c}\text { Globigerinoides } \\
\text { sacculifer }\end{array}$} & \multicolumn{2}{|c|}{$\begin{array}{c}\text { Globoquadrina } \\
\text { venezuelana }\end{array}$} \\
\hline & & $\delta^{18} \mathrm{O}$ & $\overline{\delta^{13} \mathrm{C}}$ & $\delta^{18} \mathrm{O}$ & $\delta^{13} \mathrm{C}$ & $\delta^{18} \mathrm{O}$ & $8^{8^{13} \mathrm{C}}$ \\
\hline \multicolumn{8}{|l|}{ 115-709C-(Cont.) } \\
\hline $14 \mathrm{H}-1,120-125$ & 122.60 & -0.79 & 2.64 & & & & \\
\hline $14 \mathrm{H}-1,120-125$ & 122.60 & -0.69 & 1.94 & & & & \\
\hline $14 \mathrm{H}-2,120-125$ & 124.10 & -0.72 & 2.49 & & & & \\
\hline $14 \mathrm{H}-5,120-125$ & 128.60 & -0.70 & 2.48 & & & & \\
\hline $14 \mathrm{H}-6,120-125$ & 130.10 & -1.16 & 2.87 & & & & \\
\hline $15 \mathrm{H}-1,120-125$ & 132.30 & -1.08 & 2.85 & & & & \\
\hline $15 \mathrm{H}-2,120-125$ & 133.80 & -0.80 & 3.20 & & & 0.60 & 2.13 \\
\hline $15 \mathrm{H}-3,120-125$ & 135.30 & -1.33 & 2.69 & & & & \\
\hline $15 \mathrm{H}-4,120-125$ & 136.80 & -0.36 & 1.63 & & & 0.75 & 1.37 \\
\hline $15 \mathrm{H}-5,120-125$ & 138.30 & -0.18 & 1.61 & & & & \\
\hline $15 \mathrm{H}-6,120-125$ & 139.80 & -0.32 & 2.03 & & & & \\
\hline $16 \mathrm{H}-1,120-125$ & 142.00 & -0.67 & 3.00 & & & 0.44 & 2.02 \\
\hline $16 \mathrm{H}-2,120-125$ & 143.50 & -1.28 & 3.01 & & & & \\
\hline $16 \mathrm{H}-3,120-125$ & 145.00 & -1.05 & 3.13 & & & & \\
\hline $16 \mathrm{H}-4,120-125$ & 146.50 & -0.76 & 1.91 & & & & \\
\hline $16 \mathrm{H}-5,120-125$ & 148.00 & -0.79 & 1.77 & & & & \\
\hline $16 \mathrm{H}-6,120-125$ & 149.50 & -1.22 & 1.87 & & & 0.56 & 1.19 \\
\hline $17 \mathrm{H}-1,120-125$ & 151.70 & -0.79 & 1.79 & & & & \\
\hline $17 \mathrm{H}-2,120-125$ & 153.20 & -0.58 & 1.36 & & & 0.91 & 1.12 \\
\hline $17 \mathrm{H}-3,120-125$ & 154.70 & -1.70 & 1.12 & & & & \\
\hline \multirow[t]{2}{*}{$17 \mathrm{H}-4,120-125$} & 156.20 & -1.30 & 0.91 & & & & \\
\hline & 157.70 & -1.48 & 1.68 & & & 0.51 & 1.08 \\
\hline $17 \mathrm{H}-6,120-125$ & 159.20 & -1.35 & 2.06 & & & & \\
\hline $18 \mathrm{H}-1,120-125$ & 161.40 & -1.05 & 1.48 & & & 0.45 & 1.23 \\
\hline $18 \mathrm{H}-2,120-125$ & 162.90 & -1.08 & 3.09 & & & 0.58 & 1.27 \\
\hline $18 \mathrm{H}-3,120-125$ & 164.40 & -1.01 & 2.86 & & & 0.68 & 1.30 \\
\hline $18 \mathrm{H}-4,120-125$ & 165.90 & -0.69 & 2.35 & & & 0.69 & 1.24 \\
\hline $18 \mathrm{H}-5,120-125$ & 167.40 & -0.56 & 1.96 & & & 0.74 & 1.29 \\
\hline \multirow[t]{2}{*}{$18 \mathrm{H}-6,120-125$} & 168.90 & -0.61 & 1.70 & & & 0.76 & 1.05 \\
\hline & 171.00 & -1.04 & 2.84 & & & & \\
\hline $19 \mathrm{H}-1,120-125$ & 171.10 & & & & & 0.83 & 1.42 \\
\hline $19 \mathrm{H}-2,120-125$ & 172.60 & & & & & 1.01 & 1.16 \\
\hline $19 \mathrm{H}-3,120-125$ & 174.10 & & & & & 0.85 & 1.19 \\
\hline $19 \mathrm{H}-4,120-125$ & 175.60 & & & & & 1.02 & 1.53 \\
\hline $19 \mathrm{H}-5,120-125$ & 177.10 & & & & & 0.98 & 0.96 \\
\hline $19 \mathrm{H}-6,120-125$ & 178.60 & & & & & 0.96 & 1.19 \\
\hline $20 \mathrm{H}-1,120-125$ & 180.70 & & & & & 0.60 & 1.40 \\
\hline $20 \mathrm{H}-2,120-125$ & 182.20 & & & & & 0.70 & 1.59 \\
\hline $20 \mathrm{H}-3,120-125$ & 183.70 & & & & & 0.85 & 1.74 \\
\hline $20 \mathrm{H}-4,120-125$ & 185.20 & & & & & 0.85 & 2.11 \\
\hline $20 \mathrm{H}-5,120-125$ & 186.70 & & & & & 0.90 & 2.07 \\
\hline $20 \mathrm{H}-6,120-125$ & 188.20 & & & & & 0.70 & 1.76 \\
\hline $21 X-1,120-125$ & 190.30 & & & & & 0.95 & 1.95 \\
\hline $21 X-2,120-125$ & 191.80 & & & & & 1.28 & 2.25 \\
\hline $21 X-3,120-125$ & 193.30 & & & & & 1.33 & 1.93 \\
\hline $21 X-4,120-125$ & 194.80 & & & & & 0.64 & 1.84 \\
\hline $21 X-5,120-125$ & 196.30 & & & & & 0.84 & 1.54 \\
\hline $21 X-6,120-125$ & 197.80 & & & & & 0.35 & 1.64 \\
\hline $22 \mathrm{X}-1,120-125$ & 199.90 & & & & & 0.71 & 1.32 \\
\hline $22 X-2,120-125$ & 201.40 & & & & & 1.11 & 1.81 \\
\hline $22 \mathrm{X}-3,120-125$ & 202.90 & & & & & 0.20 & 1.24 \\
\hline $22 X-4,120-125$ & 204.40 & & & & & 0.42 & 1.39 \\
\hline $22 X-5,120-125$ & 205.90 & & & & & 0.21 & 1.11 \\
\hline $23 \mathrm{X}-1,120-125$ & 209.45 & & & & & 0.81 & 1.23 \\
\hline $23 \mathrm{X}-2,120-125$ & 210.95 & & & & & 0.54 & 1.07 \\
\hline $23 \mathrm{X}-3,120-125$ & 212.45 & & & & & 0.29 & 1.20 \\
\hline $23 \times-4,120-125$ & 213.95 & & & & & 0.51 & 0.98 \\
\hline $23 \mathrm{X}-5,120-125$ & 215.45 & & & & & 0.51 & 1.31 \\
\hline
\end{tabular}

${ }^{\text {a }}$ Measurements given in parts per thousand $(\% 0)$ PDB.

that parallels the increase observed in DPF and supports the placement of level A.

A marked $\delta^{13} \mathrm{C}$ increase in $\mathrm{BF}$ near the Oligocene/Miocene boundary has been reported in various areas (e.g., Pacific Site 77, Keigwin and Keller, 1984; South Atlantic Site 522, Miller et al., 1988; North Atlantic Sites 563, 366, and 566, Miller and Fairbanks, 1985; Miller et al., 1989). The latter authors suggest that this increase is a useful marker of the Oligocene/Miocene boundary. The sharp $\delta^{13} \mathrm{C}$ increase, however, has been placed slightly below the boundary at Atlantic sites and slightly above at IndoPacific sites, a discrepancy that probably results from the different biostratigraphic criteria used to identify the Oligocene/Miocene boundary.

An interval of ${ }^{13} \mathrm{C}$ enrichment in the DPF record at Pacific Sites 574 and 575 occurs in the lower lower Miocene between levels A and B, followed by a depleted interval through a large part of the lower Miocene up to level E, which marks the start of a notable ${ }^{13} \mathrm{C}$ excursion toward heavier values in the upper lower Miocene. Level B near the Zone $\mathrm{CN} 1 \mathrm{~b} / \mathrm{CN} 1 \mathrm{c}$ boundary and in upper Zone N4 was assigned an age of $20.7 \mathrm{Ma}$ by Vincent and Killingley (1985). Level E, which approximates the Zone $\mathrm{CN} 2 / \mathrm{CN} 3$ and N6/N7 boundaries, and lies at the base of reversely 
Table 3. Oxygen and carbon isotope composition of planktonic foraminifers from Hole $758 \mathrm{~A}^{\mathrm{a}}$.

\begin{tabular}{|c|c|c|c|c|c|c|c|}
\hline \multirow{2}{*}{$\begin{array}{l}\text { Core, section, } \\
\text { interval }(\mathrm{cm})\end{array}$} & \multirow{2}{*}{$\begin{array}{l}\text { Depth } \\
\text { (mbsf) }\end{array}$} & \multicolumn{2}{|c|}{$\begin{array}{c}\text { Dentoglobigerina } \\
\text { altispira }\end{array}$} & \multicolumn{2}{|c|}{$\begin{array}{c}\text { Globigerinoides } \\
\text { sacculifer }\end{array}$} & \multicolumn{2}{|c|}{$\begin{array}{c}\text { Globoquadrina } \\
\text { venezuelana }\end{array}$} \\
\hline & & $\delta^{18} \mathrm{O}$ & ${ }_{\delta^{13} \mathrm{C}}$ & $\delta^{18} \mathrm{O}$ & $\delta^{13} \mathrm{C}$ & $\delta^{18} \mathrm{O}$ & ${ }_{\delta^{13} \mathrm{C}}$ \\
\hline \multicolumn{8}{|l|}{$121-758 \mathrm{~A}$} \\
\hline $4 \mathrm{H}-4,55-60$ & 30.25 & & & -1.46 & 1.79 & & \\
\hline $4 \mathrm{H}-5,55-60$ & 31.75 & & & -1.71 & 2.14 & & \\
\hline $4 \mathrm{H}-6,55-60$ & 33.25 & & & -1.42 & 1.60 & & \\
\hline $4 \mathrm{H}-7,55-60$ & 34.75 & & & -1.67 & 1.78 & & \\
\hline $5 \mathrm{H}-1,55-60$ & 35.35 & & & -1.67 & 1.78 & & \\
\hline $5 \mathrm{H}-2,55-60$ & 36.85 & & & -1.80 & 1.58 & & \\
\hline $5 \mathrm{H}-3,55-60$ & 38.35 & & & -1.91 & 1.55 & & \\
\hline $5 \mathrm{H}-4,55-60$ & 39.85 & -0.57 & 1.33 & -1.46 & 1.53 & & \\
\hline $5 \mathrm{H}-5,55-60$ & 41.35 & -1.62 & 1.47 & -2.16 & 1.39 & & \\
\hline $5 \mathrm{H}-6,55-60$ & 42.85 & -1.38 & 1.32 & -1.86 & 1.65 & & \\
\hline $5 \mathrm{H}-7,55-60$ & 44.35 & -1.39 & 1.33 & -1.99 & 1.34 & & \\
\hline $6 \mathrm{H}-1,55-60$ & 44.95 & -1.67 & 1.46 & -1.75 & 1.35 & & \\
\hline $6 \mathrm{H}-2,55-60$ & 46.45 & -1.77 & 1.80 & & & & \\
\hline & 46.46 & & & -1.88 & 1.51 & & \\
\hline $6 \mathrm{H}-3,55-60$ & 47.95 & -1.96 & 1.52 & -1.87 & 1.41 & & \\
\hline $6 \mathrm{H}-4,55-60$ & 49.45 & -1.57 & 1.35 & -1.69 & 1.36 & & \\
\hline $6 \mathrm{H}-5,55-60$ & 50.95 & -1.84 & 1.42 & -1.92 & 1.41 & & \\
\hline $6 \mathrm{H}-6,55-60$ & 52.45 & -1.95 & 1.51 & -2.04 & 1.75 & & \\
\hline $6 \mathrm{H}-7,55-60$ & 53.95 & -1.54 & 1.28 & -1.89 & 2.05 & & \\
\hline $7 \mathrm{H}-1,55-60$ & 54.55 & -1.92 & 1.14 & -2.10 & 1.20 & & \\
\hline $7 \mathrm{H}-2,55-60$ & 56.05 & -1.55 & 1.63 & -1.75 & 1.47 & & \\
\hline $7 \mathrm{H}-3,55-60$ & 57.55 & -1.64 & 1.60 & -1.92 & 1.84 & & \\
\hline $7 \mathrm{H}-4,55-60$ & 59.05 & -0.88 & 2.34 & -1.30 & 1.54 & & \\
\hline $7 \mathrm{H}-5,55-60$ & 60.55 & -0.86 & 2.06 & -1.76 & 1.83 & & \\
\hline $7 \mathrm{H}-6,55-60$ & 62.05 & -0.94 & 2.15 & -1.83 & 1.77 & & \\
\hline $7 \mathrm{H}-7,55-60$ & 63.55 & 0.74 & 2.09 & -1.79 & 1.73 & 0.07 & 0.48 \\
\hline $8 \mathrm{H}-1,55-60$ & 64.25 & -1.45 & 1.13 & -1.99 & 1.78 & -0.40 & 0.32 \\
\hline $8 \mathrm{H}-2,55-60$ & 65.75 & -1.59 & 0.85 & -1.89 & 1.55 & & \\
\hline $8 \mathrm{H}-3,55-60$ & 67.25 & -1.46 & 1.18 & -1.62 & 1.74 & & \\
\hline $8 \mathrm{H}-4,55-60$ & 68.75 & -1.15 & 1.65 & -1.54 & 1.85 & & \\
\hline $8 \mathrm{H}-5,55-60$ & 70.25 & -1.15 & 1.30 & -1.71 & 2.08 & -0.17 & 0.68 \\
\hline $8 \mathrm{H}-6,55-60$ & 71.75 & & & -1.74 & 2.09 & & \\
\hline $8 \mathrm{H}-7,55-60$ & 73.25 & & & -1.96 & 1.99 & & \\
\hline $9 \mathrm{H}-1,55-60$ & 73.95 & & & -1.96 & 1.89 & & \\
\hline $9 \mathrm{H}-2,55-60$ & 75.45 & -1.23 & 1.15 & -1.92 & 1.70 & & \\
\hline $9 \mathrm{H}-3,55-60$ & 76.95 & -1.81 & 1.64 & -2.01 & 1.98 & & \\
\hline $9 \mathrm{H}-4,55-60$ & 78.45 & -1.60 & 1.57 & -1.70 & 1.82 & & \\
\hline $9 \mathrm{H}-5,55-60$ & 79.95 & -1.54 & 1.41 & -1.83 & 1.48 & & \\
\hline $9 \mathrm{H}-6,55-60$ & 81.45 & -1.29 & 1.25 & -1.51 & 1.49 & & \\
\hline $10 \mathrm{H}-1,55-60$ & 83.65 & -1.09 & 0.92 & -1.07 & 1.29 & & \\
\hline $10 \mathrm{H}-2,55-60$ & 85.15 & -1.06 & 2.48 & -1.72 & 1.69 & & \\
\hline $10 \mathrm{H}-3,55-60$ & 86.65 & -1.79 & 2.04 & -1.06 & 1.65 & 0.82 & 0.49 \\
\hline $10 \mathrm{H}-4,55-60$ & 88.15 & -1.25 & 2.06 & -1.49 & 1.96 & 0.47 & 0.98 \\
\hline $10 \mathrm{H}-5,55-60$ & 89.65 & -0.84 & 2.00 & -1.58 & 1.36 & -0.13 & 0.56 \\
\hline $10 \mathrm{H}-6,55-60$ & 91.15 & -0.89 & 2.08 & -2.06 & 1.15 & 0.59 & 1.06 \\
\hline $10 \mathrm{H}-7,55-60$ & 92.65 & -1.20 & 2.16 & & & 0.67 & 1.08 \\
\hline $11 \mathrm{H}-1,55-60$ & 93.35 & -1.30 & 2.61 & & & 0.39 & 0.95 \\
\hline $11 \mathrm{H}-2,55-60$ & 94.85 & -1.13 & 2.03 & -1.91 & 1.36 & 0.80 & 1.12 \\
\hline $11 \mathrm{H}-3,55-60$ & 96.35 & -1.71 & 1.81 & -1.88 & 2.02 & 0.44 & 1.18 \\
\hline $11 \mathrm{H}-4,55-60$ & 97.85 & -1.81 & 1.87 & -1.31 & 2.17 & 0.48 & 1.41 \\
\hline $11 \mathrm{H}-5,55-60$ & 99.35 & -1.56 & 1.73 & -1.26 & 2.56 & & \\
\hline $11 \mathrm{H}-6,55-60$ & 100.85 & -1.29 & 1.47 & -1.63 & 2.07 & 0.22 & 0.90 \\
\hline $11 \mathrm{H}-7,55-60$ & 102.35 & -1.32 & 1.85 & -1.45 & 2.21 & 0.45 & 1.10 \\
\hline $12 \mathrm{H}-1,55-60$ & 102.95 & -1.60 & 1.49 & -1.24 & 1.30 & -0.08 & 1.23 \\
\hline $12 \mathrm{H}-2,55-60$ & 104.45 & -1.78 & 1.87 & -1.22 & 2.13 & 0.15 & 1.22 \\
\hline $12 \mathrm{H}-3,55-60$ & 105.95 & -1.43 & 1.82 & -1.24 & 2.14 & 0.35 & 1.20 \\
\hline $12 \mathrm{H}-4,55-60$ & 107.45 & -1.91 & 1.92 & -1.44 & 2.52 & & \\
\hline $12 \mathrm{H}-5,55-60$ & 108.95 & & & -1.69 & 2.68 & & \\
\hline $12 \mathrm{H}-6,55-60$ & 110.45 & -1.35 & 2.23 & -1.31 & 2.09 & & \\
\hline $13 \mathrm{H}-1,55-60$ & 112.65 & -1.87 & 2.74 & & & & \\
\hline $13 \mathrm{H}-2,55-60$ & 114.15 & -1.34 & 2.51 & & & & \\
\hline $13 \mathrm{H}-3,55-60$ & 115.65 & -1.62 & 2.15 & & & & \\
\hline & 117.15 & -1.54 & 1.72 & & & & \\
\hline $13 \mathrm{H}-5,55-60$ & 118.65 & -1.33 & 1.27 & & & & \\
\hline $13 \mathrm{H}-6,55-60$ & 120.15 & -1.54 & 1.76 & & & & \\
\hline $14 \mathrm{H}-2,55-60$ & 123.75 & -1.43 & 2.12 & & & 0.85 & 1.08 \\
\hline $14 \mathrm{H}-3,55-60$ & 125.25 & -1.16 & 1.70 & & & 1.36 & 1.12 \\
\hline $14 \mathrm{H}-4,55-60$ & 126.75 & -1.15 & 2.05 & & & 0.79 & 1.10 \\
\hline $15 \mathrm{H}-1,55-60$ & 131.95 & -1.76 & 2.46 & & & 0.56 & 1.35 \\
\hline $15 \mathrm{H}-2,55-60$ & 133.45 & -1.53 & 2.48 & & & 0.60 & 1.74 \\
\hline $15 \mathrm{H}-3,55-60$ & 134.95 & -2.09 & 2.83 & & & 1.67 & 1.09 \\
\hline $16 \mathrm{H}-1,55-60$ & 141.49 & -1.18 & 1.95 & & & 0.53 & 0.97 \\
\hline $16 \mathrm{H}-2,55-60$ & 143.02 & -1.21 & 1.54 & & & 0.72 & 1.07 \\
\hline $16 \mathrm{H}-3,55-60$ & 144.55 & -1.43 & 1.65 & & & 0.35 & 0.97 \\
\hline $16 \mathrm{H}-4,55-60$ & 146.02 & -1.06 & 1.92 & & & 0.26 & 1.05 \\
\hline
\end{tabular}

${ }^{\text {a }}$ Measurements given in parts per thousand $(\% 0)$ PDB. magnetized sediments attributed to magnetic anomaly 5C (Chron 16), was assigned an age of $17.5 \mathrm{Ma}$.

The succession in the lower Miocene of $\mathrm{a}^{13} \mathrm{C}$-enriched interval between $A$ and $B$ overlain by a depleted one between $B$ and $E$ was recognized by Vincent et al. (1985) in the DPF and BF records of the Indian Ocean, but its distinction at the different sites depends on the quality of the records. This succession is well displayed in the BF records of other oceans (e.g., Pacific Site 77, Keigwin and Keller, 1984; North Atlantic Sites 366, 558, 563, and 666, Miller and Fairbanks, 1985; Miller et al., 1989).

The ${ }^{13} \mathrm{C}$-enriched interval A-B is distinct in the DPF record at Site 709 between 205 and $182 \mathrm{mbsf}$ with mean $\delta^{13} \mathrm{C}$ values of about $2 \%$. It is overlain by an interval of small amplitude fluctuations with a mean value of about $1.2 \%$. Then the DPF $\delta^{13} \mathrm{C}$ values increase by about $0.8 \%$ between 150 and $142 \mathrm{mbsf}$. The $\delta^{13} \mathrm{C}$ record of the BF parallels that of the DPF, but the SPF record shows quite a different pattern with very large excursions. Because of the stratigraphic disturbance previously mentioned in the interval between 170 and $135 \mathrm{~m}$, any interpretation of isotopic data must be made with great caution in this stratigraphic interval. It is probable that the isotope record obtained between 135 and $140 \mathrm{mbsf}$, in which the $\delta^{13} \mathrm{C}$ values of BF, DPF, and SPF show a remarkably parallel excursion toward lighter values (similar to those in underlying sediments at around $160 \mathrm{mbsf}$ ), corresponds to an isotopic signal from reworked carriers as shown by the correlation between the carbon isotope excursion and calcareous nannofossils of reworked Zone CN2 age (see Fig. 3).

Placement of level E is difficult at Site 709 in the stratigraphically disturbed interval. It is probably marked by the pronounced ${ }^{13} \mathrm{C}$ enrichment in SPF and DPF at $145 \mathrm{mbsf}$, coincident with the placement of the Zone N6/N7 boundary.

At the Indian Ocean sites previously studied, level $\mathrm{E}$ is well marked by a distinct increase in $\delta^{13} \mathrm{C}$ values of the three BF, DPF, and SPF records. It marks the start of an interval of ${ }^{13} \mathrm{C}$ enrichment of about $4 \mathrm{~m}$.y. in duration. This heavy ${ }^{13} \mathrm{C}$ excursion, which is a dominant feature of the Miocene carbon isotope stratigraphy, has been called the "Monterey carbon excursion" by Vincent and Berger (1985) because it is synchronous with the deposition of organic-rich sediments around the margin of the North Pacific in the Monterey Formation of California and its equivalent. The Monterey excursion is readily identified in the DPF record of the equatorial Pacific and in the DPF and SPF records of the Indian Ocean, as well as in BF records of various oceanic regions. The initiation of the carbon excursion precedes the major mid-Miocene ${ }^{13} \mathrm{C}$ enrichment. Thus, it is possible that extraction of organic carbon preconditions the ocean-atmosphere system for subsequent cooling, an hypothesis discussed by Vincent and Berger (1985). The heavy ${ }^{13} \mathrm{C}$ carbon excursion ends with a rather gradual decline toward values approaching those preceding the excursion and terminates near, or slightly above, level $\mathrm{H}$.

At Site 709 the termination of the heavy carbon excursion occurs in the SPF and BF records near level H, as in other Indian Ocean sites. At Site 758, although the lack of an isotopic record in the lower part of the sequence hampers interpretation of lower Miocene data, it appears that the overall decreasing trend in $\delta^{13} \mathrm{C}$ values of SPF between 135 and 120 mbsf corresponds to the decline of the Monterey carbon excursion. Above that level, however, pronounced positive peaks in the $\delta^{13} \mathrm{C}$ values of SPF (especially for $D$. altispira) are difficult to interpret.

The last notable global event in the Miocene is recorded by a negative "shift" in $\delta^{13} \mathrm{C}$ values of about $0.8 \%$ in the latest Miocene, which has been tied directly to the upper reversed-polarity event of Chron 6 in the equatorial Pacific (Keigwin and Shackleton, 1980). The significance of this carbon depletion, marking the onset of the Messinian desiccation event, has been discussed extensively (Bender and Keigwin, 1979; Keigwin, 
1979; Vincent et al., 1980, among others) and it has been used as a chronostratigraphic marker in various areas.

The "Chron 6 carbon shift" is not clearly identified at Site 758 because of the discontinuous nature of the DPF isotopic record. In this record, however, the carbon shift appears to occur in the same paleomagnetic position as in the equatorial Pacific, that is, in Chron 6 event 1 (Fig. 4). Large fluctuations in the $\delta^{13} \mathrm{C}$ values of $G$. sacculifer and D. altispira prevent its clear identification on the SPF record. However, mean $\delta^{13} \mathrm{C}$ values of D. altispira above the Chron 5/Chron 6 boundary are distinctly depleted compared to the mean values below.

At previously studied Indian Ocean sites the Chron 6 carbon shift is well marked in all three BF, DPF, and SPF records, where it occurs slightly above the FO of Amaurolithus primus (which marks the Zone $\mathrm{CN} 9 \mathrm{a} / \mathrm{CN} 9 \mathrm{~b}$ boundary at $6.5 \mathrm{Ma}$ ) in the same biostratigraphic position as shown on BF records of other ocean basins (e.g. Haq et al., 1980) and as seen on the BF and SPF record at Site 709 (Fig. 3).

Parallel changes in the $\delta^{13} \mathrm{C}$ values of BF, DPF, and SPF in parallel fashion as expressed in a number of Miocene events, reflect changes in input/output ratios of organic carbon to carbonate carbon (Miller and Fairbanks, 1985; Vincent and Berger, 1985; Berger and Vincent, 1986; Shackleton, 1987).

\section{CONCLUSIONS}

This study remains preliminary because of the incompleteness of the isotopic records. However, a number of features of chronostratigraphic value, previously recognized in the equatorial Pacific and at other tropical Indian Ocean sites, are identified in the two sites analyzed. The limitation of the available sites in the tropical Indian Ocean in terms of percentage recovery, condensed nature of the record, and stratigraphic disturbance will hamper full integration of biostratigraphy, magnetostratigraphy, and isotope stratigraphy of this region. However, we believe that considerable progress toward a global low-latitude synthesis can be made by working with available or planned sites from all three oceans.

\section{ACKNOWLEDGMENTS}

We acknowledge funding to E. V. from INSU/CNRS under DBT (contribution no. 540) and IST programs, and NERC grant no. GR3/3606 to N.J.S. We thank various reviewers, especially James D. Wright, for their constructive criticisms, and Monique Toumarkine for her reliable assistance in picking the foraminifers.

\section{REFERENCES}

Backman, J., Duncan, R. A., et al., 1988. Proc. ODP, Init. Repts., 115: College Station, TX (Ocean Drilling Program).

Backman, J., Schneider, D. A., Rio, D., and Okada, H., 1990. Neogene low-latitude magnetostratigraphy from Site 710 and revised age estimates of Miocene nannofossil datum events. In Duncan, R. A., Backman, J., Peterson, L. C., et al., Proc. ODP, Sci. Results, 115: College Station, TX (Ocean Drilling Program), 271-276.

Barron, J. A., Keller, G., and Dunn, D. A., 1985. A multiple microfossil biochronology for the Miocene. In Kennett, J. P. (Ed.), The Miocene Ocean: Paleoceanography and Biogeography. Geol. Soc. Am. Mem., 163:21-36.

Bé, A.W.H., 1977. An ecological, zoogeographic and taxonomic review of Recent planktonic foraminifera. In Ramsay, A. (Ed.), Oceanic Micropaleontology (Vol. 1): London (Academic Press), 1-100.

Bender, M. L., and Keigwin, L. D., Jr., 1979. Speculations about the Upper Miocene change in abyssal Pacific dissolved bicarbonate $\delta^{13} \mathrm{C}$. Earth Planet. Sci. Lett., 45:383-393.

Berger, W. H., Killingley, J. S., and Vincent, E., 1978. Stable isotopes in deep-sea carbonates: box cores ERDC-92, west equatorial Pacific. Oceanol. Acta, 1:203-216.

Berger, W. H., and Vincent, E., 1986. Deep-sea carbonates: reading the carbon-isotope signal. Geol. Rundsch., 75:249-269.
Berggren, W. A., Kent, D. V., and Van Couvering, J. A., 1985. The Neogene: Part 2. Neogene geochronology and chronostratigraphy. In Snelling, N. J. (Ed.), The Chronology of the Geological Record. Geol. Soc. London Mem., 10:211-260.

Duplessy, J.-C., Shackleton, N. J., Matthews, R. K., Prell, W., Ruddiman, W. F., Caralp, M. and Hendy, C. H., $1984 .{ }^{13} \mathrm{C}$ record of benthic foraminifera in the last interglacial ocean: implications for the carbon cycle and the global deep water circulation. Quat. Res., 21:225-243.

Haq, B. U., Worsley, T. R., Burckle, L. H., Douglas, R. G., Keigwin, L. D., Opdyke, N. D., Savin, S. M., Sommer, M. A., Vincent, E., and Woodruff, F., 1980. Late Miocene marine carbon-isotopic shift and synchroneity of some phytoplanktonic biostratigraphic events. Geology, 8:427-431.

Imbrie, J., Hays, J. D., Martinson, D. G., McIntyre, A., Mix, A. C., Morley, J. J., Pisias, N. G., Prell, W. L., and Shackleton, N. J., 1984. The orbital theory of Pleistocene climate: support from a revised chronology of the marine $\delta^{18} \mathrm{O}$ record. In Berger, A., Imbrie, J., Hays, J., Kukla, G., and Saltzman, B. (Eds.), Milankovitch and Climate (Pt. 1): Dordrecht (D. Reidel), 269-305.

Keigwin, L. D., and Keller, G., 1984. Middle Oligocene climate change from equatorial Pacific DSDP Site 77. Geology, 12:16-19.

Keigwin, L. D., Jr., 1979. Late Cenozoic stable isotope stratigraphy and paleoceanography of DSDP sites from the east equatorial and central North Pacific Ocean. Earth Planet. Sci. Lett., 45:361-381.

Keigwin, L. D., Jr., 1987. Toward a high-resolution chronology for latest Miocene paleoceanographic events. Paleoceanography, 2:639-660.

Keigwin, L. D., Jr., and Shackleton, N. J., 1980. Uppermost Miocene carbon isotope stratigraphy of a piston core in the equatorial Pacific. Nature, 284:613-614.

Kennett, J. P., and Srinivasan, M. S., 1983. Neogene Planktonic Foraminifera: A Phylogenetic Atlas: Stroudsburg, PA (Hutchinson Ross).

Miller, K. G., and Fairbanks, R. G., 1985. Oligocene to Miocene carbon isotope cycles and abyssal circulation changes. In Sundquist, E. J., and Broecker, W. S. (Eds.), The Carbon Cycle and Atmospheric $\mathrm{CO}_{2}$ : Natural Variations Archean to Present. Am. Geophys. Union Geophys. Monogr., 32:469-486.

Miller, K. G., Fairbanks, R. G., and Mountain, G. S., 1987. Tertiary oxygen isotope synthesis, sea-level history, and continental margin erosion. Paleoceanography, 2:1-19.

Miller, K. G., Feigenson, M. D., Kent, D. V., and Olsson, R. K., 1988. Upper Eocene to Oligocene isotope $\left({ }^{87} \mathrm{Sr} /{ }^{66} \mathrm{Sr}, \delta^{18} \mathrm{O}, \delta^{13} \mathrm{C}\right)$ standard section, Deep Sea Drilling Project Site 522. Paleoceanography, $3: 223-233$.

Miller, K. G., Wright, J. D., and Brower, A. N., 1989. Oligocene to Miocene stable isotope stratigraphy and planktonic foraminifer biostratigraphy of the Sierra Leone Rise (DSDP Site 366 and ODP Site 667). In Ruddiman, W., Sarnthein, M., et al., Proc. ODP, Sci. Results, 108: College Station, TX (Ocean Drilling Program), 279-294.

Parker, F. L., 1967. Late Tertiary biostratigraphy (planktonic Foraminifera) of tropical Indo-Pacific deep-sea cores. Am. Paleontol. Bull., 52:115-203.

Peirce, J., Weissel, J., et al., 1989. Proc. ODP, Init. Repts., 121: College Station, TX (Ocean Drilling Program).

Pisias, N. G., Shackleton, N. J., and Hall, M. A., 1985. Stable isotope and calcium carbonate records from hydraulic piston cored Hole 574A; high-resolution records from the middle Miocene. In Mayer, L., Theyer, F., Thomas, E., et al., Init. Repts. DSDP, 85: Washington (U.S. Govt. Printing Office), 735-748.

Raymo, M. E., Ruddiman, W. F., Backman, J., Clement, B. M., and Martinson, D. G., 1989. Late Pliocene variation in Northern Hemisphere ice sheets and North Atlantic deep water circulation. Paleoceanography, 4:413-446.

Rio, D., Fornaciari, E., and Raffi, I., 1990. Late Oligocene through early Pleistocene calcareous nannofossils from western equatorial Indian Ocean (Leg 115). In Duncan, R. A., Backman, J., Peterson, L. C., et al.,Proc. ODP, Sci. Results, 115: College Station, TX (Ocean Drilling Program), 175-235.

Ruddiman, W.F., McIntyre, A., and Raymo, M., 1986. Matuyama 41,000year cycles: North Atlantic Ocean and northern hemisphere ice sheets. Earth Planet Sci. Lett., 80:117-129.

Savin, S. M., Abel, L., Barrera, E., Hodell, D., Kennett, J. P., Murphy, M., Keller, G., Killingley, J., and Vincent, E., 1985. The evolution of 
Miocene surface and near-surface marine temperatures: oxygen isotopic evidence. In Kennett, J. P. (Ed.), The Miocene Ocean: Paleoceanography and Biogeography. Mem. Geol. Soc. Am., 163:49-82.

Savin, S. M., and Douglas, R. G., 1985. Sea level, climate and the Central American land bridge. In Stehli, F. G., and Webb, S. D., (Eds.), The Great American Interchange: New York (Plenum), 303-324.

Savin, S. M., Douglas, R. G., and Stehli, F. G., 1975. Tertiary marine paleotemperatures. Geol. Soc. Am. Bull., 86:1499-1510.

Schneider, D. A., and Kent, D. V., 1990. Paleomagnetism of Leg 115 sediments: implications for Neogene magnetostratigraphy and paleolatitude of the Réunion hotspot. In Duncan, R. A., Backman, J., Peterson, L. C., et al., Proc. ODP, Sci. Results, 115: College Station, TX (Ocean Drilling Program), 717-736.

Shackleton, N. J., 1982. The deep-sea sediment record of climate variability. Prog, Oceanogr., 11:199-218.

1987. The carbon isotope record of the Cenozoic: history of organic carbon burial and of oxygen in the ocean and atmosphere. In Brooks, J., and Fleet, A. J. (Eds.), Marine Petroleum Source Rocks. Geol. Soc. Spec. Publ. London, 26:423-434.

Shackleton, N. J., and Hall, M. A., 1984. Oxygen and carbon isotope stratigraphy of Deep Sea Drilling Project Hole 552A: Plio-Pleistocene glacial history. In Roberts, D. G., Schnitker, D., et al., Init. Repts. DSDP, 81: Washington (U.S. Govt. Printing Office), 599-609.

1990. Pliocene oxygen isotope stratigraphy of Hole 709C. In Duncan, R. A., Backman, J., Peterson, L. C., et al., Proc. ODP, Sci. Results, 115: College Station, TX (Ocean Drilling Program), 529538.

Shackleton, N. J., Hall, M. A., and Boersma, A., 1984. Oxygen and carbon isotope data from Leg 74 foraminifers. In Moore, T. C., Jr. Rabinowitz, P. D., et al., Init. Repts. DSDP, 74: Washington (U.S. Govt. Printing Office), 599-612.

Shackleton, N. J., and Kennett, J. P., 1975. Paleotemperature history of the Cenozoic and the initiation of Antarctic glaciation: oxygen and carbon isotope analyses in DSDP Sites 277, 279 and 281. In Kennett, J. P., Houtz, R. E., et al., Init. Repts. DSDP, 29: Washington (U.S. Govt. Printing Office), 743-755.

Theyer, F., Vincent, E., and Mayer, L. A., 1989. Sedimentation and paleoceanography of the central equatorial Pacific. In Winterer, E. L.,
Hussong, D. M., and Decker, R. W. (Eds.), The Eastern Pacific Ocean and Hawaii. Geol. Soc. Am., Geol. of North Am. Ser., N:347-372.

Vincent, E., and Berger, W. H., 1985. Carbon dioxide and polar cooling in the Miocene: the Monterey Hypothesis. In Sundquist, E., and Broecker, W. S. (Eds.), The Carbon Cycle and Atmospheric $\mathrm{CO}_{2}$ : Natural Variations Archean to Present: Am. Geophys. Union, Geophys. Monogr. Ser., 32:455-468.

Vincent, E., and Killingley, J. S., 1985. Oxygen and carbon isotope record for the early and middle Miocene in the central equatorial Pacific (DSDP Leg 85) and paleoceanographic implications. In Mayer, L. Theyer, F., et al., Init. Repts. DSDP, 85: Washington (U.S. Govt. Printing Office), 749-769.

Vincent, E., Killingley, J. S., and Berger, W. H., 1980. The Magnetic Epoch- 6 carbon shift: a change in the ocean's ${ }^{13} \mathrm{C} /{ }^{12} \mathrm{C}$ ratio 6.2 million years ago. Mar. Micropaleontol., 5:185-203.

1985. Miocene oxygen and carbon isotope stratigraphy of the tropical Indian Ocean. In Kennett, J. P. (Ed.), The Miocene Ocean: Paleoceanography and Biogeography. Mem. Geol. Soc. Am., 163:103-130.

Vincent, E., and Toumarkine, M., 1990. Neogene planktonic foraminifers from the western tropical Indian Ocean, Leg 115. In Duncan, R. A., Backman, J., Peterson, L. C., et al., Proc. ODP, Sci. Results, 115: College Station, TX (Ocean Drilling Program), 795-836.

Woodruff, F., Savin, S. M., and Abel, L., 1990. Miocene benthic foraminifer oxygen and carbon isotopes, Site 709, Indian Ocean. In Duncan, R. A., Backman, J., Peterson, L. C., et al., Proc. ODP, Sci. Results, 115: College Station, TX (Ocean Drilling Program), 519528.

Woodruff, F., Savin, S. M., and Douglas, R. G., 1981. Miocene stable isotope record: a detailed deep Pacific Ocean study and its paleoclimatic implications. Science, 212:665-668.

Date of initial receipt: 9 May 1990

Date of acceptance: 6 December 1990

Ms 121B-134 